\title{
ANALISIS KONVEKSI ALAM TERAS REAKTOR TRIGA BERBAHAN BAKAR TIPE PELAT MENGGUNAKAN COOLOD-N2
}

\author{
Sudjatmi K.A. ${ }^{1}$, Endiah Puji Hastuti ${ }^{2}$, Surip Widodo ${ }^{2}$, Reinaldy Nazar ${ }^{1}$ \\ ${ }^{1}$ Pusat Sains \& Teknologi Nuklir Terapan - BATAN, Jalan Tamansari No. 71 Bandung 40132 \\ ${ }^{2}$ Pusat Teknologi \& Keselamatan Reaktor Nuklir - BATAN, Kawasan PUSPIPTEK Gd. 80, Tangsel 15310 \\ Email: sudjatmi@batan.go.id \\ Diterima editor: 20 April 2015 \\ Direvisi editor: 11 Mei 2015 \\ Disetujui untuk publikasi: 15 Mei 2015
}

\begin{abstract}
ABSTRAK
ANALISIS KONVEKSI ALAM TERAS REAKTOR TRIGA BERBAHAN BAKAR TIPE PELAT MENGGUNAKAN COOLOD-N2. Rencana penghentian produksi elemen bakar jenis TRIGA oleh produsen elemen bakar reaktor TRIGA, sudah seharusnya diantisipasi oleh badan pengoperasi reaktor TRIGA untuk menggantikan elemen bakar tipe silinder tersebut dengan tipe pelat yang tersedia di pasaran. Pada penelitian ini dilakukan perhitungan untuk model teras reaktor dengan spesifikasi utama menggunakan bahan bakar $\mathrm{U}_{3} \mathrm{Si}_{2} \mathrm{Al}$ dengan pengayaan uranium sebesar $19,75 \%$ dan tingkat muat $2,96 \mathrm{gU} / \mathrm{cm}^{3}$. Analisis dilakukan menggunakan program COOLOD-N2 yang tervalidasi pada konfigurasi teras TRIGA konversi berbahan bakar tipe pelat, yang tersusun atas 16 elemen bakar, 4 elemen kendali dan 1 fasilitas iradiasi yang terletak tepat di tengah teras. Hasil analisis menunjukkan bahwa dengan temperatur pendingin masuk ke teras sebesar $37^{\circ} \mathrm{C}$, dan rasio faktor puncak daya radial $\leq 1,92$ maka daya maksimum yang dapat dioperasikan pada moda operasi konveksi bebas adalah $600 \mathrm{~kW}$. Karakteristik termohidrolika yang diperoleh antara lain adalah temperatur pendingin di sisi outlet, kelongsong dan meat masing-masing sebesar $82,39^{\circ} \mathrm{C}, 108,88^{\circ} \mathrm{C}$, dan $109,02^{\circ} \mathrm{C}$, pada $\Delta \mathrm{T}_{\mathrm{ONB}}$ (Temperature Onset of Nucleate Boiling) $=7,18^{\circ} \mathrm{C}$ dan nilai OFIR (Onset of flow instability ratio) $=1,03$ Hasil yang diperoleh dari perhitungan ini diharapkan dapat dijadikan acuan untuk menentukan tingkat daya reaktor TRIGA berbahan bakar pelat.
\end{abstract}

Kata kunci: TRIGA Konversi, COOLOD-N2, karakteristik termohidrolika, konveksi alam, elemen bakar tipe pelat.

\section{ABSTRACT}

ANALYSIS OF NATURAL CONVECTION IN TRIGA REACTOR CORE PLATE TYPES FUELED USING COOLOD-N2. Any pretensions to stop the production of TRIGA fuel elements by TRIGA reactor fuel elements manufacturer should be anticipated by the operating agency of TRIGA reactor to replace the cylinder type fuel element with plate type fuel element that available on the market. In this study, the calculation of $U_{3} S_{2} \mathrm{Al}$ fuel with uranium enrichment of $19.75 \%$ and a load level of $2.96 \mathrm{gU} / \mathrm{cm}^{3}$ was performed. Analyses were performed using the validated COOLOD - N2 program. TRIGA conversion core configurations of fuel plate type are composed of 16 fuel elements, 4 control elements and 1 irradiation facilities which are located in the middle of core. The calculation results showed that if the cooling temperature was $37^{\circ} \mathrm{C}$, and the ratio of radial power peaking factor $\leq 1.92$, then the maximum power that can be operated on free convection mode of operation was $600 \mathrm{~kW}$. The thermalhydraulic characteristic obtained such as coolant temperature at the outlet side, cladding and meat were $82.39^{\circ} \mathrm{C}, 108.88^{\circ} \mathrm{C}$ and $109.02^{\circ} \mathrm{C}$ respectively, while the $\Delta T_{O N B}$ (Temperature Onset of Nucleate Boiling) was $7.18^{\circ} \mathrm{C}$ and OFIR (Onset of flow instability ratio) value was 1.03. The results are expected to be used as a reference for determining the power level of the TRIGA reactor core plate types fueled.

Keywords: TRIGA Convertion, COOLOD-N2, Thermalhydraulics characteristic, natural convection, plate type fuel element. 


\section{PENDAHULUAN}

Reaktor TRIGA, sesuai dengan namanya reaktor buatan General Atomic (GA) ini digunakan untuk Training, Research dan Isotop production. Sampai saat ini jumlah reaktor TRIGA di dunia mencapai 68 buah, dimana 38 reaktor dalam kondisi beroperasi, 19 reaktor tidak beroperasi dan 11 reaktor sudah didekomisioning [1]. Sebagian dari reaktor TRIGA ini ada yang beroperasi sejak tahun 1958, sedangkan yang terbaru beroperasi sejak tahun 2007. Pada rapat pengguna TRIGA tanggal 24 Maret 2010 di Marrakesh, CERCA / TRIGA Internasional mengumumkan bahwa mereka sedang mempertimbangkan untuk menghentikan pembuatan bahan bakar TRIGA [2,3].

Ketersediaan elemen bakar merupakan syarat untuk beroperasinya reaktor. Maka dengan adanya rencana penghentian tersebut, sudah selayaknya bila institusi yang memiliki dan mengoperasikan reaktor jenis TRIGA mulai memikirkan untuk mengganti elemen bakar tipe silinder dengan elemen bakar tipe pelat. Van Den Berghe Sven, dalam tulisannya menyatakan bahwa di Eropa elemen bakar tipe plat sudah banyak dipergunakan pada reaktor penelitian. Sebagian besar elemen bakar adalah elemen bakar dispersi, dimana bahan fisil terdispersi dalam matrik, biasanya adalah $\mathrm{Al}$ dengan kelongsong $\mathrm{Al}$ alloy. Bahan fisil yang digunakan adalah elemen bakar dengan pengayaan tinggi biasanya $\mathrm{UO}_{\mathrm{x}}$ atau $\mathrm{UAl}_{\mathrm{x}}$ [4]. Gede Ardana Mandala, dalam simulasinya pada reaktor TRIGA 2000 Bandung dengan bahan bakar jenis plat, menyatakan bahwa ditinjau dari aspek neutronik maupun termohidrolik, usulan penggunaan bahan bakar jenis plat layak untuk diuji [5]. Dalam karya tulis yang berjudul Termohidrolik usulan modifikasi reaktor nuklir TRIGA 2000 Bandung dengan bahan bakar jenis pelat, Gede Ardana Mandala dkk, melakukan simulasi menggunakan perangkat lunak SRAC (Standar Reactor Analysis Code) untuk mendapatkan parameter neutronik dan EUREKA untuk analisis termohidrolik [6].

Pada perancangan teras reaktor TRIGA baru atau teras reaktor TRIGA yang dimodifikasi yang selanjutnya disebut TRIGA Konversi, selain faktor neutronik, faktor termohidrolika juga penting diperhatikan. Konfigurasi teras reaktor TRIGA Konversi seperti yang ditampilkan pada Gambar 1, dapat dilihat bahwa elemen bakar reaktor berjumlah 14 buah (warna merah), batang kendali 4 buah (warna hijau) sedangkan bagian yang bewarna biru dapat digunakan sebagai fasilitas irradiasi. Material bahan bakar adalah U3Si2-Al dengan pengayaan 19,7\%, sedang material bahan penyerap adalah Ag-In-Cd [7].

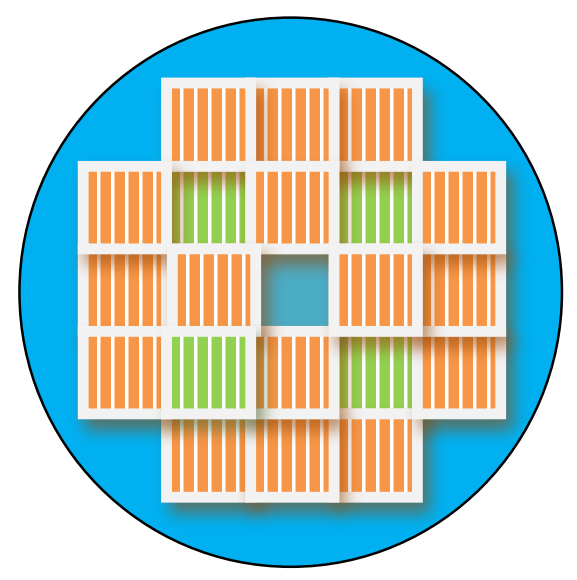

Gambar 1. Teras reaktor TRIGA Konversi.

Japan Atomic Energy Research institute (JAERI) telah mengembangkan paket program COOLOD-N2 yang merupakan modifikasi dari COOLOD-N. Program ini telah terverifikasi dengan baik dan telah digunakan untuk menganalisis karakteristik termohidrolika teras reaktor JRR-4 Jepang dan RSG-GAS di Serpong. Program COOLOD-N2 mempunyai kemampuan untuk menghitung karakteristik termohidrolika pada teras reaktor riset dengan bahan bakar berbentuk pelat maupun silinder, baik dengan moda pendinginan konveksi paksa maupun konveksi bebas atau alamiah. Program COOLOD-N2 ini telah diverifikasi untuk JRR-4 TRIGA-16 Fueled Core [8]. Pada aplikasinya, perangkat lunak ini telah dipergunakan untuk menghitung karakteristik 
termohidrolika reaktor TRIGA Bandung berelemen bakar bentuk silinder. Perhitungan dilakukan pada daya penuh dengan jumlah elemen bakar berbentuk silinder sebanyak 107 buah, untuk mengetahui karakteristik termohidrolika pada elemen bakar rerata dan elemen bakar terpanas, pada moda pendinginan konveksi bebas pada kondisi tunak [9]. Mohammad Mizanur Rahman juga melakukan perhitungan analisis keselamatan reaktor TRIGA Bangladesh mempergunakan program COOLOD-N2 [10]. Teras reaktor IEA-R1 telah dimodelkan dalam program COOLOD-N2 oleh N. $\mathrm{H}$. Badrun dkk. dengan tujuan untuk memvalidasi dan memverifikasi program tersebut terhadap data percobaan yang disediakan oleh Badan Tenaga Atom Internasional (IAEA) melalui proyek penelitian terkoordinasi (CRP). Hasil verifikasi memperlihatkan bahwa secara umum program COOLOD-N2 baik dan cocok untuk analisis reaktor penelitian dalam keadaan tunak dengan pendekatan yang baik [11]. Y. Boulaicha, menggunakan Kode COOLOD-N2 dan Paret / ANL untuk analisis termalhidrolik dan keselamatan kondisi tunak reaktor 2MW TRIGA MARK II di Pusat Studi Nuklir Maâmora (CENM), Maroko. Untuk memvalidasi model Paret / ANL dan COOLOD-N2 , dihitung suhu pusat bahan bakar sebagai fungsi daya pada teras dan dibandingkan dengan hasil eksperiment. Perbandingan menunjukkan bahwa hasil perhitungan sesuai dengan hasil pengukuran [12].

Dalam makalah ini dipaparkan hasil analisis termohidrolika konveksi alam teras reaktor TRIGA berelemen bakar tipe pelat. Perhitungan dilakukan menggunakan program Coolod-N2. Perhitungan analisis termohidrolika dilakukan pada daya penuh dengan jumlah elemen bakar 16 buah (warna merah), 4 buah elemen kendali (warna hijau) dan 1 buah fasilitas irradiasi (warna biru) seperti tertera pada Gambar 1, pada moda pendinginan konveksi bebas keadaan tunak. Sebagai data masukan, reaktor divariasikan pada daya berbagai tingkat daya, sehingga diharapkan hasil perhitungan ini dapat dijadikan bahan pertimbangan mengenai tingkat daya yang akan dipakai pada pengoperasian reaktor TRIGA Konversi yang aman.

\section{TEORI}

\section{Deskripsi Program COOLOD-N2.}

COOLOD-N2 adalah program perhitungan yang digunakan untuk menganalisis karakteristik termohidrolika teras reaktor riset pada kondisi tunak. Program ini merupakan pengembangan dari program COOLOD-N yang semula hanya untuk menghitung parameter termohidrolika pada elemen bakar berbentuk pelat. Adanya perubahan/modifikasi yang dilakukan memungkinkan digunakannya COOLOD-N2 untuk menganalisis parameter termohidrolika teras reaktor berbahan bakar bentuk silinder. Moda pendinginan konveksi paksa dan konveksi bebas dapat diselesaikan dengan COOLOD-N2.

\section{Model perhitungan distribusi temperatur elemen bakar tipe pelat}

Diasumsikan bahwa pembangkitan panas di dalam elemen bakar dianggap konstan sepanjang arah radial (ketebalan) $\left(Q=q / y_{U}=\right.$ konstan). Model distribusi temperatur pada elemen bakar tipe pelat ditunjukkan pada Gambar 2. 


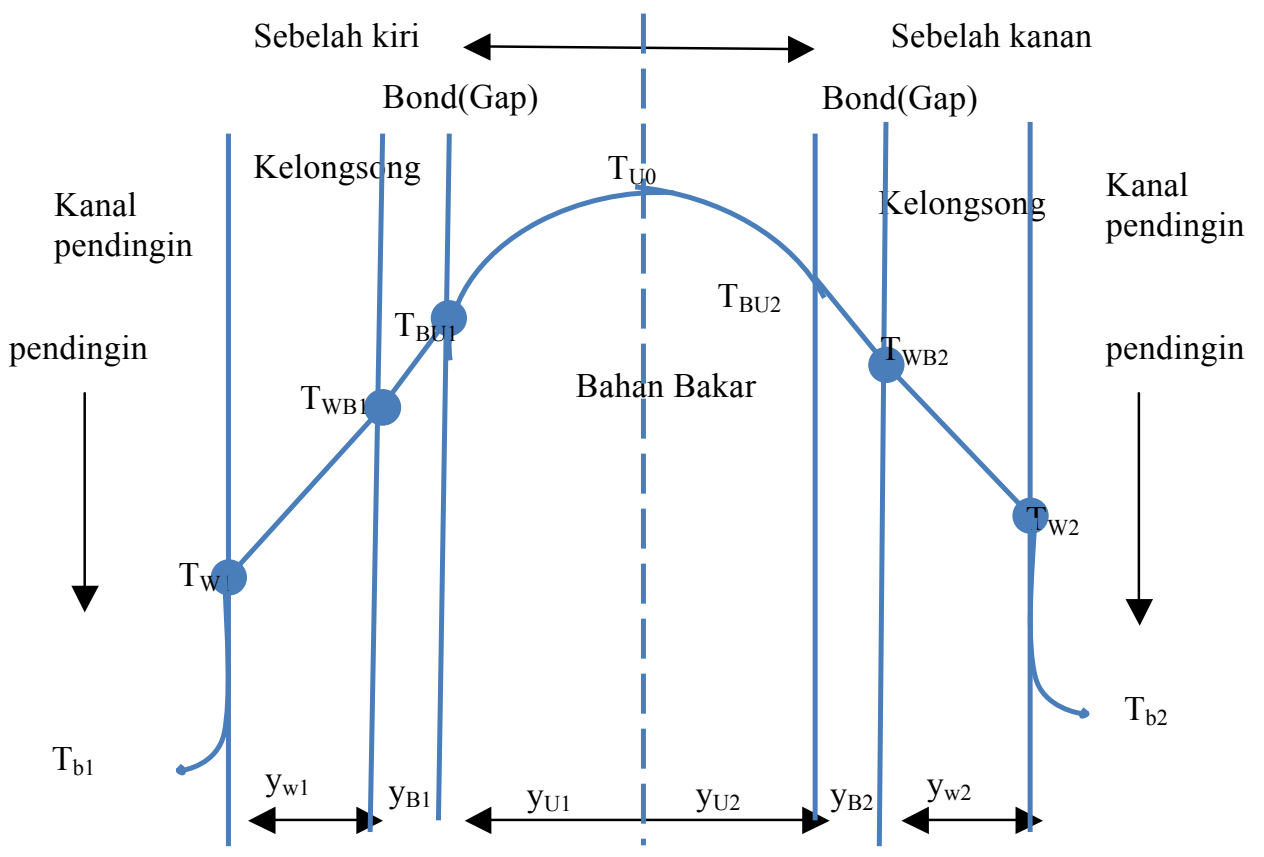

Gambar 2. Model perhitungan temperatur elemen bakar tipe pelat [8].

Bila kondisi pendinginan elemen bakar tipe pelat pada sisi sebelah kanan berbeda dengan sisi sebelah kiri, maka perangkat lunak COOLOD-N2 akan menghitung temperatur maksimum bahan bakar sampai temperatur bahan bakar pada arah sebelah kanan dan sebelah kiri sama dengan jalan mengubah lokasi temperatur maksimum. Apabila pendinginan pada sisi sebelah kanan sama dengan pendinginan pada sisi sebelah kiri, maka temperatur maksimum bahan bakar terletak di tengah bahan bakar [8]. Dengan mempertimbangkan konduksi panas satu dimensi, distribusi temperatur dalam pelat bahan bakar dihitung dengan menggunakan persamaan (1-5) [8].

1. Temperatur pendingin bulk: $\mathrm{T}_{\mathrm{b}}$

$$
T_{b}=T_{i n}+F_{b} \frac{1}{G A C_{p}{ }^{* 3600}} \int_{0}^{L} Q(Z) d Z
$$

2. Temperatur permukaan luar kelongsong: $\mathrm{T}_{\mathrm{W}}$

$$
T_{W}=T_{b}+F_{f} \frac{q}{h}
$$

3. Temperatur permukaan kelongsong bagian dalam: $\mathrm{T}_{\mathrm{WB}}$

$$
T_{W B}=T_{W}+F_{W} q y_{w} \cdot / k_{w}
$$

4. Temperatur permukaan bahan bakar: $\mathrm{T}_{\mathrm{BU}}$

$$
T_{B U}=T_{W B}+F_{B} q y_{B} / k_{B}
$$

5. Temperatur maksimum bahan bakar: $\mathrm{T}_{\mathrm{Uo}}$

$$
T_{U o}=T_{B U}+F_{U}\left\{\left(q / y_{u}\right) / 2 k_{u}\right\} y_{U}^{2}
$$

dengan

$T_{\text {in }} \quad$ : temperatur masukan pendingin, ${ }^{\circ} \mathrm{C}$

$T_{b} \quad$ : temperatur bulk pendingin, ${ }^{\circ} \mathrm{C}$

$T_{w} \quad$ : temperatur permukaan luar pelat, ${ }^{\circ} \mathrm{C}$ 
$T_{W B} \quad$ : temperatur permukaan dalam pelat, ${ }^{\circ} \mathrm{C}$

$T_{B U} \quad$ : temperatur permukaan luar bahan bakar, ${ }^{\circ} \mathrm{C}$

$T_{U O}$ : temperatur maksimum bahan bakar, ${ }^{\circ} \mathrm{C}$

$F_{b} \quad$ : faktor kenaikan temperatur bulk

$F_{f} \quad$ : faktor kenaikan temperatur film

$F_{w} \quad$ : faktor kenaikan temperatur pelat

$F_{B}$ : faktor kenaikan temperatur batas antara pelat dengan bahan bakar

$F_{u} \quad$ : faktor kenaikan temperatur bahan bakar

$G \quad$ : laju aliran massa, $\mathrm{kg} / \mathrm{m}^{2}$ det

$A \quad$ : luas aliran, $\mathrm{m}^{2}$

$C_{p} \quad$ : panas spesifik, $\mathrm{kcal} / \mathrm{kg}{ }^{\circ} \mathrm{C}$

$Q \quad$ : laju pembangkitan panas, $\mathrm{kcal} / \mathrm{jam}$

$q \quad$ : fluks panas, $\mathrm{kcal} / \mathrm{m}^{2} \mathrm{jam}$

$h \quad$ : koefisien perpindahan panas konveksi, $\mathrm{W} / \mathrm{cm}^{2}{ }^{\circ} \mathrm{C}$

$k \quad$ : konduktivitas termal, $\mathrm{W} / \mathrm{cm}{ }^{\circ} \mathrm{C}$

$y_{w} \quad$ : tebal pelat, $\mathrm{cm}$

$y_{B} \quad:$ tebal bond, $\mathrm{cm}$

$y_{U} \quad$ : tebal bahan bakar, $\mathrm{cm}$

\section{Model perhitungan pendinginan konveksi alam}

Persamaan dasar yang digunakan pada model perhitungan ini adalah persamaan kekekalan massa antara kanal yang dipanaskan dengan kanal yang tidak dipanaskan. Laju alir massa yang melalui kanal bypass teras reaktor $\mathrm{G}_{\mathrm{j}}$ akan sebanding dengan laju alir massa yang melewati kanal yang dipanaskan $\mathrm{G}_{\mathrm{i}}[8]$, yang dapat dinyatakan dengan persamaan (6).

$$
\sum_{i=1} G_{i}=\sum_{j=1} G_{j}=G_{o}
$$

Korelasi antara kehilangan tekanan di dalam kanal yang dipanaskan di dalam teras reaktor adalah $\Delta \mathrm{P}_{\mathrm{ci}}\left(\mathrm{I}=1\right.$ sampai $\left.\mathrm{I}_{\text {maks. }}\right)$, korelasi kehilangan tekanan di dalam kanal yang tidak dipanasi (bypass) $\Delta \mathrm{P}_{\mathrm{bj}}\left(\mathrm{j}=1\right.$ samapai $\left.\mathrm{j}_{\text {maks. }}\right)$, dengan gaya dorong $\Delta \mathrm{P}_{\mathrm{di}}\left(\mathrm{I}=1\right.$ sampai $\left.\mathrm{I}_{\text {maks. }}\right)[6,7]$ dinyatakan dengan persamaan (7-8).

$$
\begin{gathered}
\Delta P_{c i}\left(G_{i}\right)+\Delta P_{b j}\left(G_{j}\right)=\Delta P_{d i}\left(G_{i}\right) \\
\Delta P_{b j}\left(G_{j}\right)=\Delta P_{b}(\text { kons tan })
\end{gathered}
$$

Gaya angkat (driving force) dalam pendinginan konveksi bebas dinyatakan dengan perbedaan antara densitas pendingin kanal yang dipanaskan dan kanal yang tidak dipanaskan (by pass). Besarnya gaya angkat yang menyebabkan terjadinya perpindahan panas fluida pendingin pada moda pendinginan ini dihitung berdasarkan distribusi temperatur pendingin sepanjang kanal pendingin. Besarnya distribusi temperatur tersebut bergantung pada pembangkitan daya reaktor [8]

\section{Batas Keselamatan}

Batas keselamatan adalah batasan variabel proses di mana pengoperasian fasilitas reaktor riset telah terbukti aman. Batas keselamatan diperlukan untuk melindungi integritas dari penghalang fisik utama yang penjaga terhadap pelepasan radioaktif yang tidak terkendali di semua tahap operasional dan kecelakaan dasar desain. Pada kebanyakan reaktor riset, penghalang fisik utama adalah kelongsong elemen bahan bakar, yang suhunya dipertahankan di bawah batas tertentu dengan pendinginan sehingga integritas kelongsong terjamin. Pemilihan batas keselamatan sangat penting dan harus benar-benar dipertimbangkan dan ditentukan dengan pendekatan konservatif [13].

Sebagai contoh, $\mathrm{T}_{\mathrm{ONB}}$ (Temperature Onset of Nucleate Boiling) sering digunakan untuk menetapkan batas keselamatan, dimana $\mathrm{T}_{\mathrm{ONB}}$ merupakan kondisi yang tidak diinginkan tetapi bukan kondisi tidak aman untuk reaktor. DNB (departure from nucleate boiling) dan OFIR (Onset 
of flow instability ratio) merupakan kondisi yang jika didekati terlalu dekat memiliki arti penting bagi keselamatan. Oleh karena itu kondisi ini dapat digunakan untuk menetapkan batas keselamatan [13].

\section{METODOLOGI}

Masukan COOLOD-N2 diambil dan dihitung dari data geometri teras reaktor TRIGA (Gambar2), data parameter elemen bakar standar (Gambar 3) dan elemen bakar kendali tipe pelat (Gambar 4) seperti yang tercantum pada Tabel 1. Elemen bakar standar terdiri dari 21 buah pelat bahan bakar, sedangkan elemen bakar kendali terdiri dari 15 pelat bahan bakar dan diapit oleh bahan penyerap. Material bahan bakar adalah $\mathrm{U}_{3} \mathrm{Si}_{2} \mathrm{Al}$, sedangkan material bahan penyerap adalah Ag-In-Cd. Material kelongsong elemen bakar standar maupun kendali adalah $\mathrm{AlMg}_{2}$

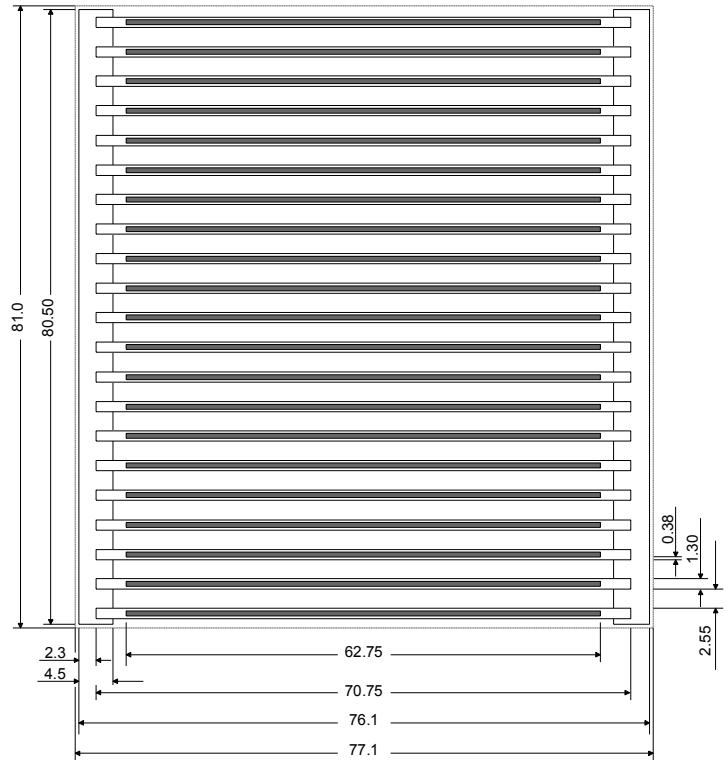

Gambar 3. Elemen bakar standar [14].

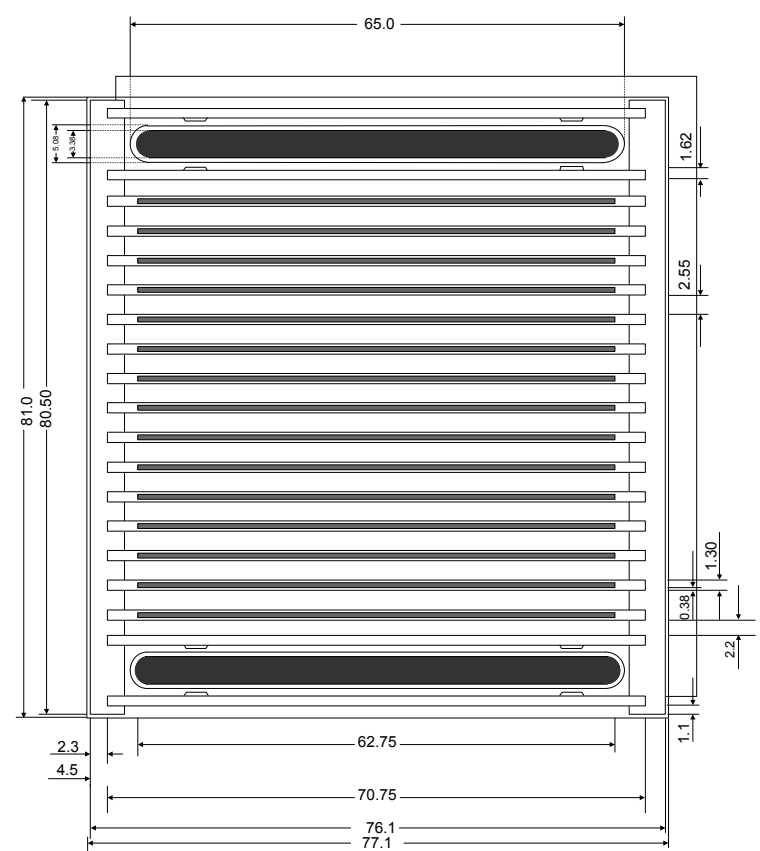

Gambar 4. Elemen bakar kendali [14].

Tabel 1. Data elemen bakar dan elemen kendali tipe pelat [14].

\begin{tabular}{ll}
\hline PARAMETER & NILAI \\
\hline Dimensi elemen bakar \& kendali $(\mathrm{mm})$ & $77,1 \times 81 \times 600$ \\
Tebal pelat elemen bakar $(\mathrm{mm})$ & 1,3 \\
Lebar kanal pendingin $(\mathrm{mm})$ & 2,55 \\
Jumlah pelat tiap elemen bakar & 21 \\
Jumlah pelat tiap elemen kendali & 15 \\
Material kelongsong elemen bakar & $\mathrm{AlMg}_{2}$ \\
Tebal kelongsong elemen bakar $(\mathrm{mm})$ & 0,38 \\
Dimensi bahan bakar $(\mathrm{mm})$ & $0,54 \times 62,75 \times 600$ \\
Material bahan bakar & $\mathrm{U}_{3} \mathrm{Si} \mathrm{i}_{2} \mathrm{Al}$ \\
Pengkayaan U-235 (w/o) & 19,75 \\
Densitas Uranium dalam bahan bakar $\left(\mathrm{g} / \mathrm{cm}^{3}\right)$ & 2,96 \\
Jumlah U-235 tiap elemen bakar $(\mathrm{g})$ & 250 \\
Jumlah U-235 tiap elemen kendali $(\mathrm{g})$ & 178,6 \\
Material absorber & $\mathrm{Ag}-\mathrm{In}-\mathrm{Cd}$ \\
\hline
\end{tabular}


Perhitungan mempergunakan perangkat lunak COOLOD-N2 ini dilakukan pada beberapa tingkat daya yaitu $400 \mathrm{~kW}, 500 \mathrm{~kW}, 600 \mathrm{~kW}, 1000 \mathrm{~kW}$ dan $2000 \mathrm{~kW}$. Pada daya $600 \mathrm{kw}$, dilakukan perhitungan karakteristik termohidrolik pada berbagai nilai rasio faktor puncak daya ( $p p f=$ =eaking power factor ratio) arah radial.

\section{HASIL DAN PEMBAHASAN}

Pada pengoperasian reaktor penelitian, salah satu pembatas keselamatan yang perlu diperhatikan adalah faktor kemampuan pengambilan panas yang dibangkitkan di dalam teras, dalam hal ini operasi reaktor penelitian dibatasi oleh daya, sesuai batasan keselamatan yang ditetapkan. Perhitungan dilakukan dengan menggunakan perangkat lunak COOLOD-N2. Data dan parameter yang digunakan tertera pada Tabel 1, Gambar 3, dan 4, sedangkan hasil perhitungan dapat dilihat pada Gambar 5, 6, 7, 8 dan Tabel 2

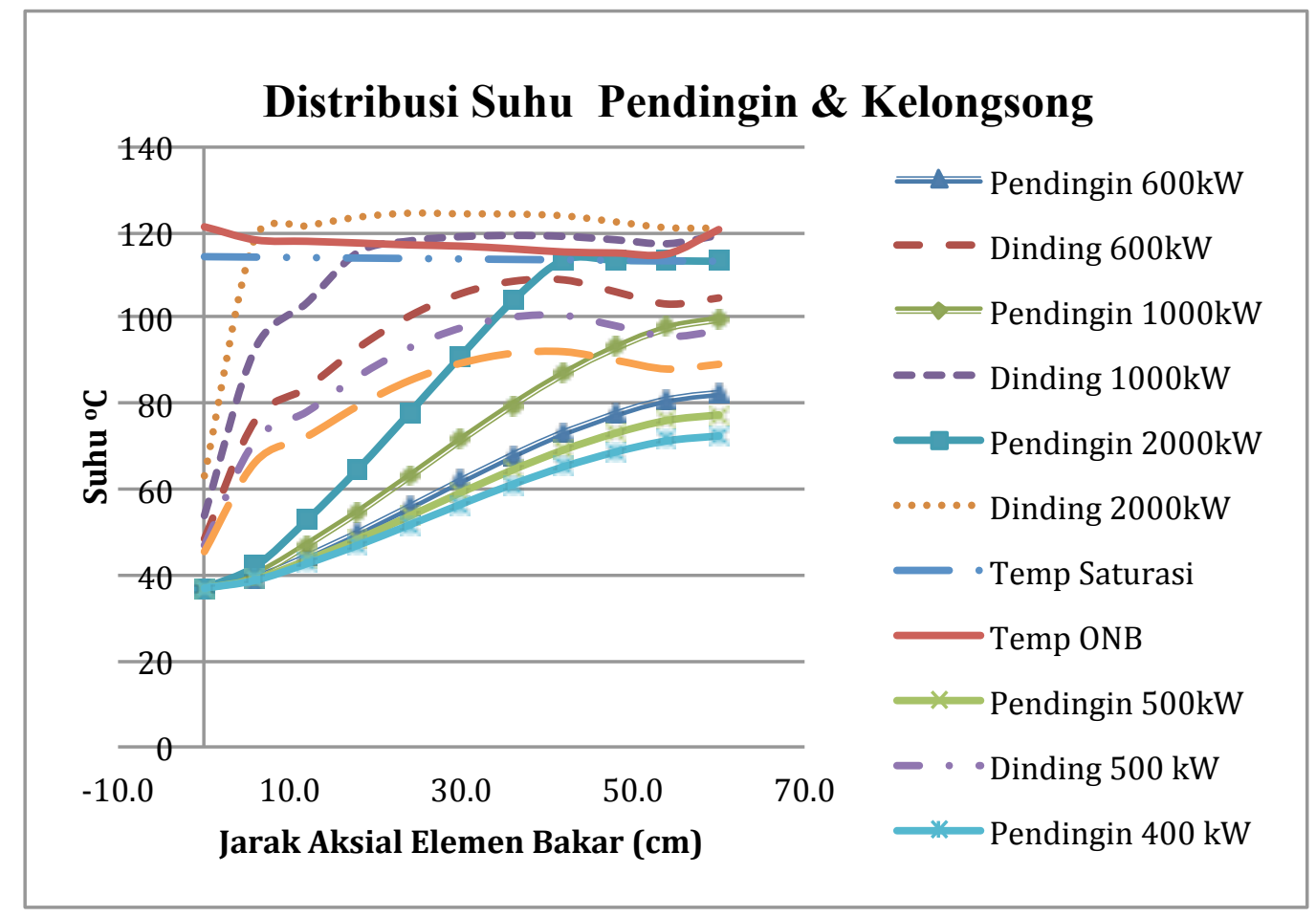

Gambar 5. Karakteristika temperatur pendingin, dinding elemen bakar pada daya $400 \mathrm{~kW}, 500 \mathrm{~kW}, 600 \mathrm{~kW}$, $1000 \mathrm{~kW}$ dan $2000 \mathrm{~kW}$ serta temperatur saturasi dan $\mathrm{T}_{\mathrm{ONB}}$ sebagai fungsi tinggi elemen bakar pada kanal terpanas.

Tabel 2. Hasil Perhitungan Termohidrolika Reaktor TRIGA Konversi

\begin{tabular}{cccccccc}
\hline $\begin{array}{c}\text { Daya } \\
\begin{array}{c}\text { Reaktor } \\
(\mathrm{MW})\end{array}\end{array}$ & $\begin{array}{c}\text { T Pendingin } \\
\text { in/out }\left({ }^{\circ} \mathrm{C}\right)\end{array}$ & $\begin{array}{c}\mathrm{T} \\
\text { Kelongsong } \\
\left({ }^{\circ} \mathrm{C}\right) \max \end{array}$ & $\begin{array}{c}\mathrm{T} \text { Meat } \\
\left({ }^{\circ} \mathrm{C}\right) \\
\max \end{array}$ & $\begin{array}{c}\Delta \mathrm{T} \text { ONB } \\
\left({ }^{\circ} \mathrm{C}\right) \min \end{array}$ & $\begin{array}{c}\mathrm{T} \\
\text { Saturasi } \\
\left({ }^{\circ} \mathrm{C}\right) \min \end{array}$ & $\begin{array}{c}\text { OFIR } \\
\text { min }\end{array}$ & $\begin{array}{c}\text { DNBR } \\
\text { Min }\end{array}$ \\
\hline 400 & $37,0 / 72,5$ & 92,14 & 92,23 & 23,49 & 113,20 & 1,31 & 7,79 \\
500 & $37,0 / 77,41$ & 100,58 & 100,69 & 15.27 & 113,20 & 1,15 & 6,59 \\
600 & $37,0 / 82,39$ & 108,88 & 109,02 & 7,18 & 113,20 & 1,03 & 5,71 \\
1000 & $37,0 / 99,71$ & 119,25 & 119,51 & $-3,02$ & 113,20 & 0,74 & 3,82 \\
2000 & $37,0 / 113,23$ & 124,28 & 125,02 & $-8,43$ & 113,20 & 0,47 & 2,21 \\
\hline
\end{tabular}

Gambar 5 menunjukkan karakteristik temperatur pendingin dan dinding elemen bakar pada daya $400 \mathrm{~kW}, 500 \mathrm{~kW}, 600 \mathrm{~kW}, 1000 \mathrm{~kW}$ dan $2000 \mathrm{~kW}$ serta temperatur saturasi dan temperatur ONB sebagai fungsi tinggi elemen bakar pada kanal terpanas. Tabel 2 merangkum hasil 
perhitungan termohidrolika dan marjin keselamatan pada variabel daya. COOLOD-N2 memberikan hasil perhitungan pada kanal terpanas.

Hasil perhitungan pada daya $400 \mathrm{~kW}$ dan $500 \mathrm{~kW}$ menunjukan bahwa delta terjadinya pendidihan inti ( $\triangle \mathrm{T}$ ONB) masih cukup besar yaitu $23,49^{\circ} \mathrm{C}$ dan $15,27^{\circ} \mathrm{C}$. Nilai marjin terjadinya akhir pendidihan inti (DNBR) dan rasio terjadinya instabilitas aliran (OFIR) $>1$, yang berarti reaktor aman bila dioperasikan pada temperatur ini.

Pada daya $600 \mathrm{~kW}$, temperatur pendingin di sisi outlet adalah $82,39^{\circ} \mathrm{C}$, temperatur ini belum melampaui temperatur saturasi. Temperatur dinding kelongsong 108,88 dan temperatur meat $109,02{ }^{\circ} \mathrm{C}$ juga belum mencapai nilai temperatur saturasi, meskipun demikian perlu diwaspadai delta terjadinya pendidihan inti hanya sebesar $7,18^{\circ} \mathrm{C}$. Dari hasil perhitungan, pengoperasian reaktor pada daya $600 \mathrm{~kW}$ menghasilkan rasio terjadinya instabilitas aliran mencapai nilai 1,03 1, berarti telah berada pada batas keselamatan, sementara mencapai DNBR masih $>1$ yaitu 5,71. Meskipun demikian hal ini perlu diwaspadai karena salah satu batas keselamatan sudah dicapai yaitu nilai OFIR 1,03 1

Temperatur pendingin di sisi keluaran pada daya $1000 \mathrm{~kW}$ adalah $99,71^{\circ} \mathrm{C}$ masih dibawah temperatur saturasi. Meskipun demikian pada kondisi ini pendidihan telah terjadi. Hal ini ditunjukan dengan data temperatur kelongsong dan temperatur meat yang telah melampaui temperatur saturasi, demikian pula awal terjadinya pendidihan inti telah terlampaui, rasio instabilitas aliran $0,74<1,00$. Semua parameter pembatas keselamatan termohidrolika telah terlampaui, kecuali DNBR 3,82. Untuk moda pendinginan konveksi bebas lebih aman menggunakan marjin terhadap awal terjadinya pendidihan inti $\left(\mathrm{T}_{\mathrm{ONB}}\right)$.

Xiuzhong Shen dkk., dalam tulisannya menyatakan bahwa salah satu kriteria keselamatan Kyoto University Research Reactor (KUR) adalah DNBR > 1,5 [15]. Pengoperasian Dalat Nuclear Research Reactor juga dibatasi oleh DNBR > 1,5 [16].

\section{Karakteristik termohidrolika reaktor TRIGA berbahan bakar silinder dan TRIGA Konversi}

Untuk memberikan ilustrasi mengenai perbedaan karakteristik termohidrolika reaktor TRIGA dan TRIGA Konversi menggunakan bahan bakar tipe pelat, pada Tabel 3 ditampilkan hasil perhitungan termohidrolika reaktor menggunakan COOLOD-N2 pada kedua jenis bahan bakar tersebut. Nilai $2000 \mathrm{~kW}$ dipilih untuk mengetahui perbandingan karakteristik temperatur dan marjin keselamatan kedua jenis bahan bakar tersebut. Hasil perhitungan dirangkum di dalam Tabel 3.

Tabel 3. Hasil perhitungan termohidrolika reaktor TRIGA \& reaktor TRIGA Konversi pada daya $2000 \mathrm{~kW}$

\begin{tabular}{lcccccc}
\hline Jenis Reaktor & $\begin{array}{c}\text { T Pendingin } \\
\text { in/out }\left({ }^{\circ} \mathrm{C}\right)\end{array}$ & $\begin{array}{c}\text { T Kelongsong } \\
\max \left({ }^{\circ} \mathrm{C}\right)\end{array}$ & $\begin{array}{c}\text { T Meat max } \\
\left({ }^{\circ} \mathrm{C}\right)\end{array}$ & $\begin{array}{c}\text { T Saturasi } \\
\left({ }^{\circ} \mathrm{C}\right)\end{array}$ & OFIR & DNBR \\
\hline TRIGA[7] & $32,2 / 113,43$ & 137,49 & 685,15 & 113,43 & - & 1,95 \\
TRIGA Konversi & $37,0 / 113,23$ & 124,28 & 125,02 & 113,20 & 0,47 & 2,21 \\
\hline
\end{tabular}

Pada Tabel 3 terlihat bahwa pendidihan inti telah terjadi karena temperatur pendingin telah mencapai temperatur jenuh, akan tetapi marjin keselamatan DNBR yang ditetapkan untuk bahan bakar tipe silinder belum terlampaui. Pada Laporan Analisis Keselamatan Reaktor TRIGA 2000 Bandung, ditentukan marjin keselamatan DNBR adalah 1,38 [17]

Hasil perhitungan TRIGA Konversi berbahan bakar pelat menunjukkan bahwa temperatur pendingin telah mendidih $\left(113,23^{\circ} \mathrm{C}\right)$ mulai $10 \mathrm{~cm}$ dari sisi input hingga sisi outlet yang berakibat terjadinya instabilitas aliran yang ditunjukkan dengan nilai OFIR sebesar 0,47 dimana nilai ini jauh di bawah nilai marjin keselamatan 1,00. Marjin keselamatan lainnya menunjukkan bahwa telah terjadi pendidihan di permukaan kelongsong $\left(124,45^{\circ} \mathrm{C}\right)$, temperatur jenuh juga telah terlampaui. Hal ini menunjukkan bahwa TRIGA Konversi tidak memenuhi marjin keselamatan dari aspek termohidrolika apabila dioperasikan pada daya tinggi, lebih besar dari pada $600 \mathrm{~kW}$. Pada daya 600 $\mathrm{kW}$ pun perlu diwaspadai karena nilai OFIR berada pada batas keselamatan. 


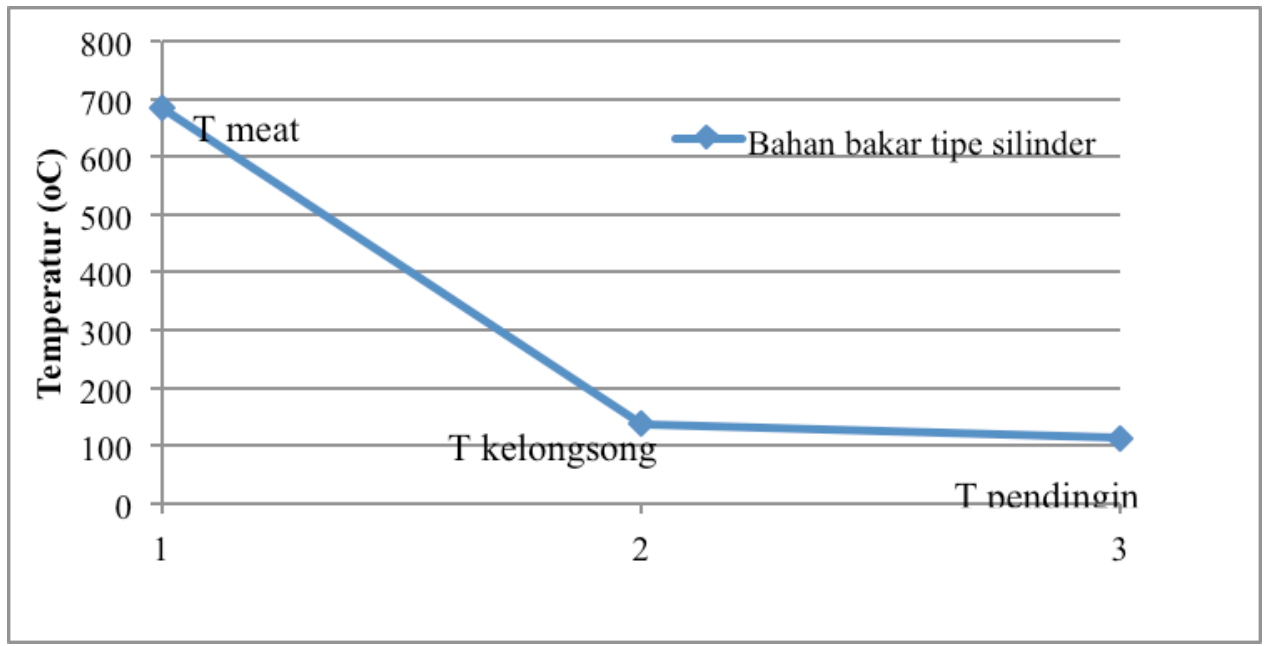

Gambar 6. Karakteristik TRIGA berbahan bakar tipe silinder pada daya $2000 \mathrm{~kW}$

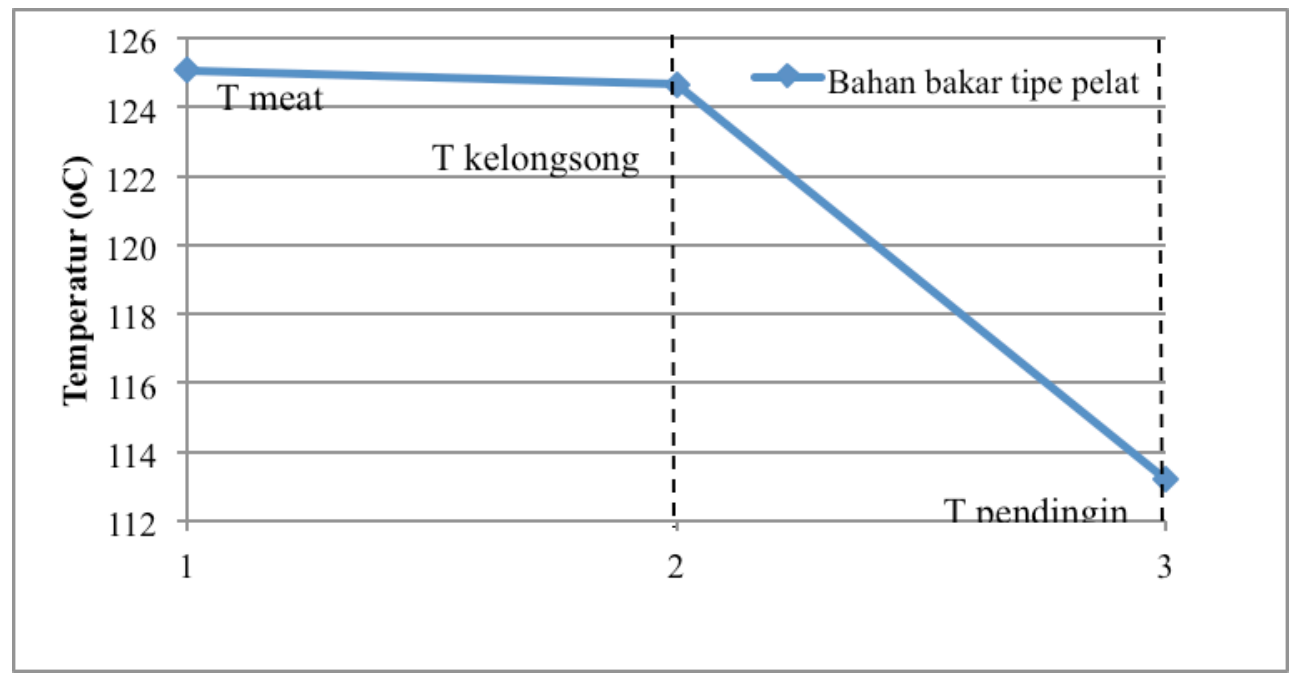

Gambar 7. Karakteristik TRIGA Konversi berbahan bakar tipe pelat pada daya 2000 kW

Karakteristik temperatur bahan bakar dari tengah bahan bakar hingga pendingin keluar di sisi outlet kanal pendingin untuk bahan bakar tipe silinder dan tipe pelat masing-masing ditunjukkan pada Gambar 7 dan 8. Pada bahan bakar silinder tampak bahwa penurunan temperatur meat ke kelongsong sangat signifikan sementara delta temperatur dari kelongsong ke pendingin sebesar $24,06^{\circ} \mathrm{C}$. Hal ini disebabkan karena bahan bakar bentuk silinder memiliki diameter jauh lebih besar dibandingkan dengan tebal meat di dalam pelat.

Pada bahan bakar tipe pelat, temperatur meat dan kelongsong hampir sama karena dimensi meat dan kelongsong sangat tipis, sementara itu delta temperatur kelongsong ke pendingin sebesar $11,23^{\circ} \mathrm{C}$. Temperatur pendingin sudah mencapai nilai saturasinya, pendidihan inti telah terjadi. Kedua hal di atas menunjukkan bahwa pengoperasian TRIGA Konversi dengan moda pendinginan konveksi bebas pada daya $2000 \mathrm{~kW}$ tidak memenuhi marjin keselamatan.

\section{Karakteristik termohidrolika TRIGA Konversi, pada daya $600 \mathrm{~kW}$}

Dari hasil analisis diatas, diperoleh bahwa TRIGA Konversi tidak memenuhi marjin keselamatan apabila dioperasikan pada daya lebih besar dari pada $600 \mathrm{~kW}$. Pada daya $600 \mathrm{~kW}$ pun perlu diwaspadai karena nilai OFIR berada pada batas keselamatan. Pengoperasian reaktor TRIGA pada daya terpilih $600 \mathrm{~kW}$, memerlukan syarat batas faktor puncak daya radial yang terkait dengan konfigurasi elemen bakar di dalam teras reaktor, karena hal ini berpengaruh pada nilai perbandingan daya puncak radial dengan daya rata-ratanya. Pada Gambar 10 ditunjukkan 
karakteristik temperatur pendingin pada daya $600 \mathrm{~kW}$ pada berbagai nilai rasio faktor puncak daya (ppf=peaking power factor ratio) arah radial. Pada Gambar 11 ditunjukkan karakteristik OFIR pada daya $600 \mathrm{~kW}$ pada berbagai nilai rasio ppf arah radial. Pada gambar tersebut dapat dilihat bahwa pada rasio ppf arah radial sebesar $>2$ OFIR sudah mencapai nilai 1,00 . Sehingga perlu diperhatikan, bila rasio ppf sudah mencapai nilai $>2$, maka perlu dilakukan pengaturan ulang posisi elemen bakar agar nilai rasio ppf dapat dipertahankan $<2$ sehingga pengoperasian reaktor tetap terjaga aman karena rasio terjadinya awal instabilitas aliran belum terjadi.

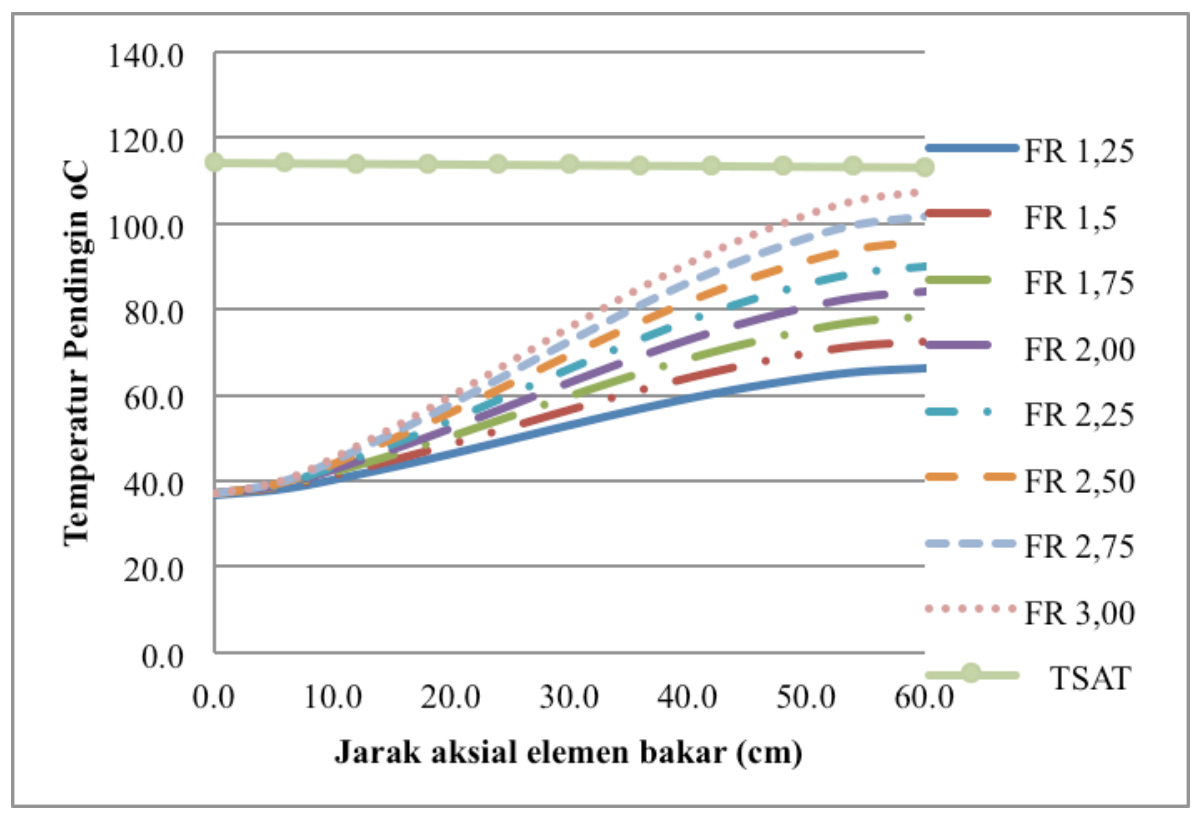

Gambar 8. Karakteristik temperatur pendingin pada daya $600 \mathrm{~kW}$ pada berbagai nilai rasio ppf arah radial

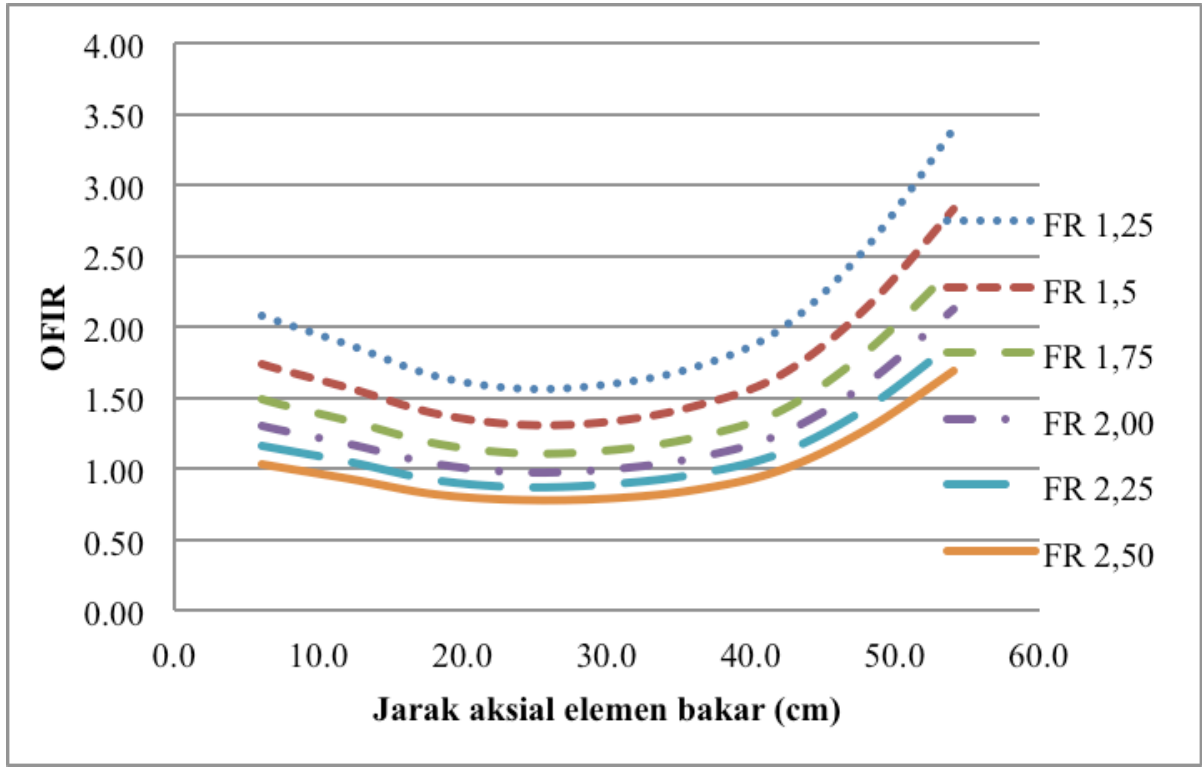

Gambar 9. Karakteristik OFIR pada daya $600 \mathrm{~kW}$ pada berbagai nilai rasio $p p f$ arah radial 


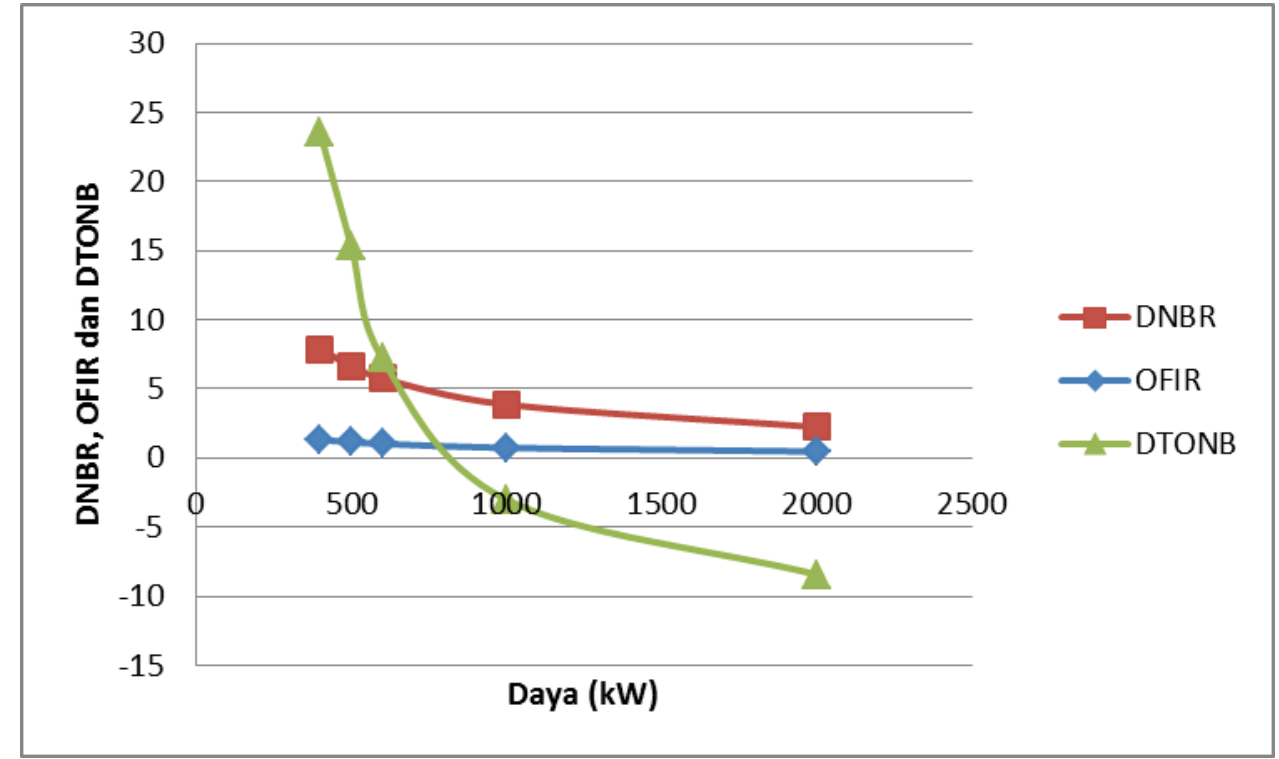

Gambar 10. DNBR, OFIR dan DTONB pada berbagai tingkat Daya

Gambar 9 menunjukkan bahwa temperatur pendingin dipengaruhi oleh variasi faktor puncak daya radial ( $F R=$ factor radial) dari 1,25 hingga 3,0. Temperatur pendingin di sisi outlet bahan bakar meningkat sebagai fungsi bertambahnya nilai ppf, tampak bahwa semua variant FR belum mencapai nilai saturasinya, meskipun demikian semakin jauh delta antara temperatur pendingin outlet dengan nilai Tsat, akan meningkatkan marjin keselamatannya.

Gambar 10 menunjukkan bahwa nilai OFIR di posisi setengah tinggi bahan bakar $(30 \mathrm{~cm})$ yang merupakan nilai minimumnya, dipengaruhi oleh nilai FR. Tampak pada gambar tersebut, nilai OFIR 1,00 dicapai apabila nilai $F R=2,00$. Semakin rendah rasio FR maka nilai OFIR semakin besar, yang berarti reaktor semakin aman.

\section{KESIMPULAN}

Hasil perhitungan TRIGA Konversi berbahan bakar pelat mempergunakan program COOLOD$\mathrm{N} 2$ menunjukkan bahwa pada daya $2000 \mathrm{~kW}$ pendingin telah mendidih $\left(\mathrm{T}=113,23^{\circ} \mathrm{C}\right)$ dan terjadi instabilitas aliran yang ditunjukkan dengan nilai OFIR $=0,47$, dimana nilai ini jauh di bawah nilai marjin keselamatan 1,00. Hal ini menunjukkan bahwa TRIGA Konversi tidak memenuhi marjin keselamatan dari aspek termohidrolika apabila dioperasikan pada daya tinggi. Moda pendinginan konveksi bebas pada reaktor TRIGA berbahan bakar tipe pelat membatasi pengoperasian daya reaktor pada daya maksimum $600 \mathrm{~kW}$ dengan rasio faktor puncak daya FR $\leq 2,00$. Agar reaktor dapat dioperasikan dengan daya yang lebih tinggi dari $600 \mathrm{~kW}$, disarankan agar pendinginan dilakukan dengan moda pendinginan paksa.

\section{DAFTAR PUSTAKA}

1. IAEA, Generic Procedures for Response to a Nuclear or Radiological Emergency at TRIGA Research Reactors, EPR-Triga Research Reactor, IAEA, Vienna, 2011.

2. H. Suwarno, Development of TRIGA Fuel Fabrication by Powder Technique, Atom Indonesia Vol. 40 No. 3, 2014: 113.

3. G. Hampel, The Importance of TRIGA Reactors, on Behalf of the European TRIGA community, Johannes Gutenberg-Universitat Mainz D-55099, 9th April 2010 
4. VAN DEN BERGHE Sven, LEENAERS Ann, KOONEN Edgar and SANNEN Leo, From High to Low Enriched Uranium Fuel in Research Reactors, Advances in Science and Technology Vol. 73 2010: 78-90.

5. Gede Ardana Mandala, Simulasi Modifikasi Reaktor TRIGA 2000 Bandung Dengan Bahan Bakar Jenis Pelat, SEMINAR NASIONAL VI, SDM TEKNOLOGI NUKLIR, YOGYAKARTA, 18 NOVEMBER 2010, ISSN 1978-0176, hal. 769 - 774.

6. Gede Ardana Mandala, Sihana, Andang Widi Harto, Termohidrolik usulan modifikasi reaktor nuklir TRIGA 2000 Bandung dengan bahan bakar jenis pelat, Prosiding Seminar Keselamatan Nuklir 2011, ISSN: 1412 - 3258, BAPETEN, JAKARTA, 27 - 28 Juni 2011, hal. $254-265$

7. Prasetyo Basuki, Putranto Ilham Yazid, Zaki Zuud, Desain Neutronika Elemen Bakar Tipe Pelat pada Teras Triga 2000 Bandung, Jurnal Sains dan Teknologi Nuklir Indonesia, Vol. 15, No.2, 2014: 69 -79.

8. KAMINAGA M. COOLOD-N2: A Computer Code For The Analyses of Steady-State Thermal Hydraulics in Research Reaktors. 1994 March. Report No.: JAERI-M, 94-052.

9. Sudjatmi K.A., Endiah Puji Hastuti. Aplikasi Program Coolod-N2 Untuk Analisis Termohidrolik Teras Reaktor TRIGA. Prosiding Seminar Nasional Sains dan Teknik Nuklir Bandung; 14 - 15 Juni 2005, Puslitbang Teknik Nuklir - BATAN; 2005, hal. 312-319.

10. Mohammad Mizanur Rahman, Mohammad Abdur R. Akond, Mohammad Khairul Basher, Md. Quamrul Huda. Steady-State Thermal-Hydraulic Analysis of TRIGA Research Reactor. World Journal of Nuclear Science and Technology, 4, 2014: 81-87.

11. N. H. Badrun, M. H. Altaf and M. J. H. Khan, Validation of COOLOD-N2 Code Through Benchmark Calculations of IEA-R1 Reactor, The Nucleus 51, No. 4 2014: 444-447.

12. Y. Boulaich, B. Nacir, T. El Bardouni, M. Zoubair, B. El Bakkari, O. Merroun, C. El Younoussi, A. Htet, H. Boukhal, E. Chakir. Steady-state thermal-hydraulic analysis of the Moroccan TRIGA MARK II reactor by using PARET/ANL and COOLOD-N2 codes, Nuclear Engineering and Design 241, 2011: 270-273.

13. Safety Guide No. NS-G-4.4 Standards Operational Limits and Conditions and Operating Procedures for Research Reactors. International Atomic Energy Agency, Vienna, 2008.

14. Sembiring TM., Pinem S., Setiyanto. Validation of the Monte Carlo Code MVP on the First Criticality of Indonesian Multipurpose Reactor. http://www-pub.iaea.org /MTCD/publications/PDF/P1360_ICRR_2007_CD/Papers/T.M.\%20Sembiring.pdf. Diunduh Maret, 2013.

15. Xiuzhong Shen, Ken Nakajima, Hironobu Uneski, Kaichiro Mishima. Reactivity insertion transient analysis for KUR low-enriched uranium silicide fuel core. Annals of Nuclear Energy 62 2013: 195-207.

16. Luong Ba Vien, Le Vinh Vinh, Huynh Ton Nghiem, Nguyen Kien Cuong. Design Analyses for Full Core Conversion of The Dalat Nuclear Research Reactor. Nuclear Science and Technology, vol. 4, No. 1 2014: 10-25.

17. Anonim, Laporan Analisis Keselamatan Reaktor TRIGA 2000 Bandung, Revisi 3, 2006. 